\title{
Preserving Humorous Effects in a Target Language: Challenges in Translating Culturally Loaded Expressions
}

\author{
Rizky Lutviana*, Siti Mafulah \\ English Education Department-Universitas Kanjuruhan Malang \\ Jl. S. Supriadi No.48 Kota Malang, 65148. E-mail: lutviana.rizky@unikama.ac.id*
}

\begin{abstract}
Translating humorous discourse presents a big challenge for the translators, frequently although the intended meaning is transferred; the humorous effect may be lost due to different cultural terminologies. This research aims to unveil the challenge to translate the cultural specific words that contributed to the funny effect in a Diary of a Wimpy Kid series graphic novel. The first volume of the novel was chosen as the data source. The data were analyzed using Vandaele humor translation theory. The culturally loaded expressions words found include the words from the three foreign cultural words categories including material culture (24\%), social culture (55\%), and gestures and habits $(21 \%)$. The challenges in preserving humorous effect dealt with the the choice of words/terminologies that could be understood by most readers, the connotative words that are full of intepretations, and the movements that were expressed in onomatopoeic words. It is suggested that the translator should develop the sense of humor and it is also important to consider the readers' sense of humor.
\end{abstract}

Key Words: humor translation, culture, graphic novel

\begin{abstract}
Abstrak: Menerjemahkan wacana humoris menyajikan tantangan besar bagi para penerjemah, seringkali, meskipun makna yang dimaksudkan ditransfer; efek lucu mungkin hilang karena terminologi budaya yang berbeda. Penelitian ini bertujuan untuk mengungkap tantangan dalam menerjemahkan kata-kata dalam budaya tertentu yang berkontribusi pada efek lucu dalam serial novel grafis Diary of a Wimpy Kid. Volume pertama dari novel ini dipilih sebagai sumber data. Data dianalisis dengan menggunakan teori terjemahan humor Vandaele. Ekspresi kata-kata yang sarat budaya yang ditemukan termasuk katakata dari tiga kata kategori budaya asing termasuk materi budaya (24\%), sosial budaya (55\%), dan gerak tubuh dan kebiasaan (21\%). Tantangan dalam mempertahankan efek lucu dilakukan dengan menggunakan pilihan kata-kata atau istilah yang dapat dipahami oleh sebagian besar pembaca, kata-kata konotatif yang memiliki interpretasi banyak, dan gerakan yang diungkapkan dalam kata-kata onomatope. Disarankan bahwa penerjemah harus mengembangkan rasa humor dan juga penting untuk mempertimbangkan perasaan humor pembaca.
\end{abstract}

Kata kunci: lelucon terjemahan, budaya, novel grafis

Humor cannot be separated from daily practices; it is common for us to use humor to spice up conversationin order to maintain warm and closer relationship. In entertainment industry, such as in fiction, humor is considered as one of popular genres. The Diary of a Wimpy Kid is one of the humor novel with a unique form, the combination of novel and cartoon. This novel gains its popularity and translated into 40 languages including Bahasa Indonesia.

Due to this unique form, humor in this novel comprises of three broad categories of humor namely cultural humor, universal humor, and language based hu- mor, that is linguistic humor (Jabbari \& Ravisi, 2012). However, this present study would highlight the cultural humor and the translation strategy. Cultural humor is humor that is related to cultural matters such as customs or the name of certain places, works or people and the use of idioms, catchphrases, or proverbs (Jabbari \& Ravisi, 2012, p. 265). In addition, Newmark (1988, p. 95) proposes 5 cultural categories of the translation of 'foreign' cultural words: (1) ecology: flora and fauna, (2)material culture (artefacts): food, clothes, houses and town, (3) social culture: work and leisure, (4) organizations, customs, activities, procedures, 
concepts: political and administrative, religious, artistic and (5) Gestures and habits.

Translating humorous discourse presents a big challenge for the translator. Vandaele (2002) notices that there are four characteristics of humor that hinder the job of translator. First, humor is frequently associated with laughter, yet Vandaele discovers that humor and laughter are different things. "Laughter-unlike humor-does not require a developed human minds that thinks in symbols" (Vandaele, 2002). This indicated that laughter is not always associated with humor comprehension. The translator needs to be sensitive in understanding laughter resulting from humor. Second, humor comprehension and humor production are two distinct skills. People may understand humor but not all can create humor successfully. In this case the translator may perceive humor but difficult to transfer the funny effect on a target language. Third, "the appreciation of humor varies individually". The sense of humor of every person is different. And fourth, humor creation that is bound to rhetorical effect, such as pun and wordplay, is hard to translate. The translator may not be able to decode the rethorical effect and transfer it to target language as well as its rethorical effect.

Several studies have been done to identify the difficulties and challenges in translating humor, such as Veiga (2009), Sirbu (2016), and Ardeshiri \& Zarafshan (2014). Veiga (2009) analyzed the challenge in translating audiovisual humor, namely the subtitling of Forrest Gump movie. To identify the challenge, she compared the original text (English) with the translated/ subtitled version that was written in Portuguese. She noticed that verbal humor requires a special treatment, "not only as far as linguistic mechanisms are concerned, but also regarding the universe of paralinguistic elements (such as prosodic elements like tone, pitch, rhythm)" (Veiga, 2009).

The challenge was that humor in audiovisual translation is limited by technical (acoustic, and visual synchronization), linguistic and cultural constraints. Thus, she explained that it is important for the translator to have three competences in translating humor in audiovisual media. The competences include: (1) technical competence (subtitling techniques), (2) translation competence (linguistic and communicative), and (3) humor complicity (humor sensitivity-humor awareness).

Focusing on humor creation based on social and cognitive views, Sirbu (2016) conducted study about humor superiority (humor in a form of abuse, mockery, aggression, malice, and derision) and humor incongruity (humor that is created by giving contrastive and confusing effect to the reader or audience) on a two series of popular novel Three Men in a boat and Three Men on the Bummel. Sirbu (2016) identified the difficulties in translating humor with regard to inequivalence translation on incongruity humor and the translation of superiority humor except the aggression category. He concluded that the difficulty was dealing with situations that produced funny surprise in both incongruity and superiority humor. The equivalence was achieved when the translator transferred the funny surprise to the target language.

Ardeshiri \& Zarafshan (2014) considering cultural issues in analyzing 50 Iranian humorous books. They used the theory of Newmark's (1998) metaphors translation theory, Lakoff and Johnson's (1978) metaphors classification, and Yarmohammadi's (1993) consideration in translating metaphors to formulate the strategy in translating humor. The data were the result of translated book by four experts. They concluded that in translating humor, cultural elements contributed much on the effect of humor translation. The translators employed cultural strategies, that were using the terms that could be understood by most readers from different cultures. In this case, the translator put emphasize on the target text.

The previous studies give insight that in translating cultural humorin the graphic novel, namely The Diary of a Wimpy Kid, the translator should consider the paralinguistic elements (such as prosodic elements like tone, pitch, rhythm), translator competences, and culture. However, different from the previous studies, this present study recognized the challenge in translating cultural humor by applying Vandaele (2002) humor translation theory and classifying the data findings using Newmark (1988, p. 95) proposes five cultural categories of the translation of 'foreign' cultural words.

Vandaele (2002, p. 156) viewed humor as a cognitive effect and therefore the principle in translating humor is to transfer the "same humorous effect" in a target language. He then explained the complexity and the challenges in translating humor that is"the operational definition of humor is 'single'yet the structure of humor is double, consisting the cause and the effect of humor, and the meaning is "potentially multiple", in the sense that the translator or reader may deal with many meaning intepretations (ibid.). In this case, the translator should identify what is funny for him/herself, and try to grasp reader's humor sense, and be aware that the result of their translation may be perceived differently by readers. 


\section{METHODS}

This study is descriptive qualitative in which the purpose is to identify the challenges the translator faced when translating culturally-loaded expression words in a cultural humor found in the first volume of the humor graphic novel The Diary of a Wimpy Kid. The first volume was chosen as the data source because the topic of the story contained cultural specific events of western culture such as Halloween and Thanksgiving ceremony. The data were collected and recorded on the checklists and document analysis. The researcher analyzed the challenge in translating cultural humor by applying Vandaele's (2002) humor translation theory and classifying the data findings using Newmark (1988, p. 95) who proposes five cultural categories of the translation of 'foreign' cultural words.

\section{RESULTSAND DISCUSSIONS}

There were three out of five cultural categories of the translation of foreign cultural words found in the graphic novel The Diary of a Wimpy Kid, those were (1) material culture, (2) social culture, and (3) Gestures and habits; the cultural humor from the category of ecology and organization was not found since the settings of the story were mostly inhouse and school surrounding. The frequency distribution of each category can be seen in Table 1 .

\section{Table 1. The Frequency Distribution of Each Category}

\begin{tabular}{llll}
\hline No & Category & Frequency & Percentage \\
\hline 1. & Material culture & 13 & $24 \%$ \\
2. & Social culture & 29 & $55 \%$ \\
3. & Gestures and habits & 11 & $21 \%$ \\
\hline Total & & 53 & $100 \%$ \\
\hline
\end{tabular}

The third category, "organizations, customs, activities, procedures, concepts", seemed to be the most frequent data found. In the story, many foreign conceptual words that described customs and activities existed in the novel, besides the first category, that is material culture.

\section{Material Culture}

Material culture found in the text consisted of food (4 data), clothes ( 2 data), and houses and town (7 data). The challenges the translator faced in translating material culture foreign words were whether or not the translator should translate the word literally or keep the word untranslated, as elaborated in Example 1 and Example 2.

\section{Example 1}

Source Text

But I decided if I don't want to get twisted into a pretzel for the next month and a half, I'd better do my homework on this wrestling business. (Page 77)

Target Text

Tapi aku memutuskan, kalau tidak ingin terpelintir seperti kue pretzel selama satu setengah bulan berikutnya, sebaiknya aku mempersiapkan diri dalam menghadapi masalah gulat ini. (Halaman 77)

\section{Example 2}

\section{Sorce Text}

But that didn't stop us from coming to the cafetaria for the free hot chocolate they hand out to the other Patrols before homeroom.

\section{Target Text}

Namun, itu tidak berarti kami tidak bisa mengunjungi kafetaria untuk menikmati minuman cokelat panas yang mereka bagikan untuk para pengawas sebelum masuk ke homeroom*. (Halaman 153)

*Homeroom = kelas tempat setiap siswa ha-
rus melapor pada jam-jam tertentu.

In Example 1, the translator did not translate the word pretzel, yet he added the word "kue" to give information to the reader that pretzel is a kind of biscuit. However, it seemed that the reader may not perceive the funny effect, since pretzel was used to illustrate what happen to the character if he did not want to practice for wrestling, and that was what made it funny. Conversely, in example 2, the translator explained the word homeroom clearly to the reader by giving footnote. This made the reader grasp the meaning.

The next challenge for the translator to transfer the humorous effect in a target language is to find the equivalence of terminology for certain concept such as Halloween costume. In Example 3 the phrase "Toilet Paper Mummy" was translated to "MUMMY TISU GULUNG". In Indonesia, the popular term for toilet paper is "tisu gulung" (a long roll tissue paper). Unlike Americans, Indonesians rarely use toilet paper 
to clean themselves when they have been to the toilet, in this case the translator emphasize the form rather than the function of the tissue.

\section{Example 3}

\section{Source Text}

I've never had a store-bought costume before. I still haven't figured out what I'amgonna go as tomorrow night, so I'll probably just throw something together at the last minute. I figure maybe I'll bring back the Toilet Paper Mummy again. (Page 62)

Target Text

Aku belum pernah memiliki kostum yang dibeli dari toko. Aku masih belum tahu hendak menyamar sebagai apa besok malam. Jadi, aku mungkin akan membuat kostum seadanya pada detik terakhir. Kurasa aku akan kembali menghidupkan tokoh MUMMY TISU GULUNG. (Halaman 62)

\section{Social Culture}

Newmark (1988, p. 98) notes that in translating social culture foreign word, the translator should consider "denotative and connotative problems of translation". Connotative difficulties of words include the translation of reference of something that is often indicated with the phrase "the people", "the common people", etc. In other words, it dealt with implicit meaning of the text. Example 4 illustrates the challenge in translating connotative phrase "falling for that one". The intended meaning of that phrase is "to be tricked into believing something that is not true" and the reference "that one" refers to the trick Rodrick did to the main character. In English, the vocabulary is richer to denote the word "trick"(an action which purpose is to deceive, either as cheating, or joking for entertainment). It synonymous with the words cheat (dishonest), and prank (a trick that is intended to be funny but not to cause harm or damage). What is meant by "that one" in the Example 4 is prank. However, it is hard to find the equivalent meaning of the word "prank" in Bahasa Indonesia. The word "Kibulan" was Javanese vernacular for the word prank. Consequently, reader from outside Java may not understand the meaning of that word. It is better for the translator to keep the more general word that represent prank, that is "lelucon". This word can be understood by most Indonesians.

\section{Example 4}

Source Text

A couple of days into summer vacation, Rodrick woke me up in the middle of the night. He told me I slept through the whole summer, but that luckily I woke up just in time for the first day of school. You might think I was pretty dumb for falling for that one. (Page 11)

\section{Target Text}

Beberapa hari pertama diawali liburan musim panas, Rodrick membangunkanku di tengah malam. Dia bilang aku ketiduran sepanjang musim panas, tetapi aku beruntung bisa bangun tepat waktu pada hari pertama masuk sekolah. Kalian pasti berfikir aku terlalu bodoh untuk percaya pada kibulan seperti itu. (Halaman 11)

\section{Example 5}

\section{Source Text}

Rodrick's in some hot water with Mom right now, too. Manny got ahold of one of Rodrick's heavy metal magazines, and one of the pages had a picture of a woman in a bikini lying across the hood of a car. And then Manny brought it into day care for show-and-tell. (Page 41.)

\section{Target Text}

Sekarang, Rodrick juga sedang direbus oleh Mom. Manny menemukan salah satu majalah heavy metal Rodrick, dan pada salah satu halaman terdapat foto wanita berbalut bikini yang sedang berbaring di atas kap mobil. Kemudian, Manny membawa majalah itu ke tempat penitipan anak untuk acara tunjukkan-dan-ceritakan. (Halaman 41)

Another challenge in translating social culture foreign word can be seen in Example 5. "Show-andtell" is a school activity for young children in which a child brings an object into the class and talks to the other children about it (Cambridge Advanced Learner's dictionary). This activity is not common in Indonesia, the challenge faced by translator in translating this term is to find the equivalent term. In this case, the translator used literal translation method "tunjukkan-dan-ceritakan". 


\section{Gestures and Habits}

Gesture can be defined as a movement of the hands, arms or head, etc. to express an idea or feeling (Cambridge Advanced Learner's dictionary). In the novel, most of the gestures came from the movement and the sound of human's emotion, for instance when they scream, laugh, grumble, etc.

In Example 6 and Example 7, the challenge that the translator faced was to translate the movements that were expressed in onomatopoeic words or literally explain the movement to the readers. In this case the translator should understand the movement and associate it with the setting and the situation described in the cartoon. In Example 6, the word "Scream" was the expression of fear of something, in this case the "Cheese touch". It is better for the translator to translate the expression of scream of fear in a target language, that is "AAAAAAA".

Moreover, in the Example 7, "Grunt" is the noise sound of pig, we may intepret that the author used this word to show that the character were very tired of pulling the snow. The same thing also with the word "wheeze" which means a high, rough noise while breathing because of some breathing difficulty, this word emphasized that the characters were really tired and they spent much energy. The challenge that the translator faced was whether he sould translate the movement or the emotion as the effect of the movement. In this case the translator chose literal translation to translate the movement.

\section{CONCLUSION}

To sum up, translating humor in graphic novel required the translator to be aware of humor and translate humor based on the situation and the context of the source text. In perserving humorous effect on a target text, the challenges that the translator faced were on the choice of words/terminologies that could be understood by most readers. In translating material culture foreign words, the translator should be sensitive in identifying the readers' familiarity with the foreign words used. If the words were internationally popular, it is not translated.

Moreover, in translating social culture foreign words, the challenge was dealing with connotative words that are full of intepretation. Besides, in dealing with culture specific expression, it is hard to find the word with exact meaning in target text, because the lack of terminology in target text. Next, in translating gestues, the challenge was to translate the movements that were expressed in onomatopoeic words and trans-
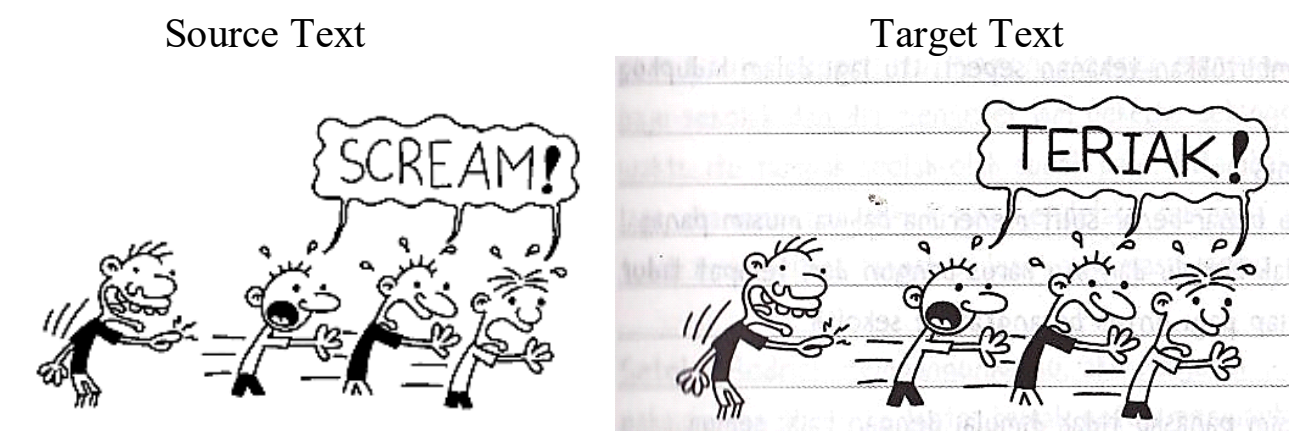

Figure 1. The Original and the Translation Gesture of "Screaming" (Example 6)

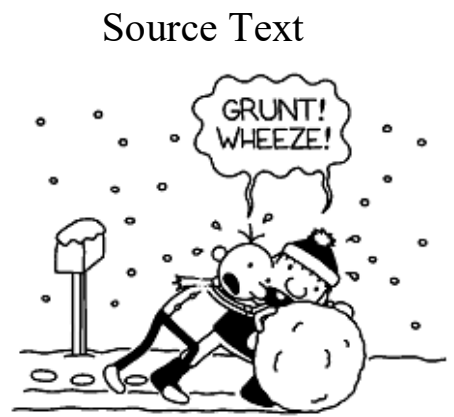

Target Text

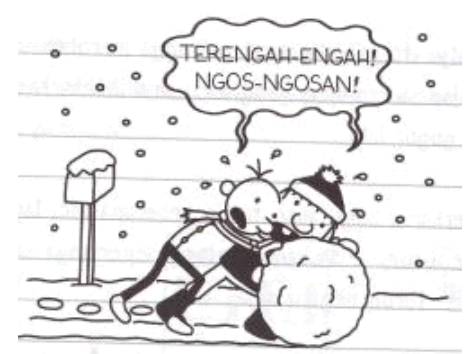

Figure 2. The Original and the Translation of Gesture "Pulling the Snow" (Example 7) 
fer it to the target text based on the given situation to evoke the humorous effect.

Regarding the conclusion, it is suggested for the translator to develop the sense of humor, and really understand the joke that he/she going to translate. Besides, it should be kept in mind that in preserving the humorous effect, the translator should consider the acceptability of the word/terminology they use in target text. In other words, it is also important to consider the readers' sense of humor.

\section{REFERENCES}

Ardeshiri, M., \& Zarafshan, M. (2014). Culture Specific Strategies as a Framework to Reduce English Language Translation American Animations in Persian Context. International Journal of Humanities and Social Science, 2(5),263-270. doi:10.17758/uruae.uh 0117412.

Chiaro, D. 2005. "Verbally Expressed Humor and Translation: An overview of a neglected field" in humor, Interna-tional Journal of HumorResearch. Special Issue in Humor and Translation. Berline: De Gruyeter. 18(2), 135-145.
Jabbari, A. A., \& Ravizi, Z. N. (2012). Dubbing Verbally Ex-pressed Humor: An Analysis of American Anima-tions in Persian Context. International Journal of Humanities and Social Science. USA: Centre for Promoting Ideas, 2(5), 263-270.

Kinney, J. (2007). The Diary Of A Wimpy Kid . New York: Amulet Books.

Kinney, J. (2009). Diary Si Bocah Tengil. Translated by Ferry Halim. Jakarta: Atria.

Lakoff, G \& Johnson, M. (1980). Metaphors We Live by. Chicago: The University of Chicago Press.

Sîrbu, I. P. (2016). Equivalence in Humour Superiority and Incongruity Translation: A Case of Three Men in a Boat and Three Men on the Bummel. Linguistics and Literature Studies, 4(3), 221-231. doi:10.13189/ lls.2016.040306

Vandaele, J. 2002. (Re-) Constructing Humour: Meanings and Means. The Translator, 8(2): 149-172. doi:10.1080/13556509.2002.10799130.

Veiga, M. J. (n.d.). Linguistic Mechanisms of Humor Subtitling. In 4th Forum for Linguistic Sharing. Retrieved from www.clunl.edu.pt/.../linguistic $\% 20$ mechanisms\%20of\%20humour\%20subtitling.pdf. Yarmohammadi, L. (1993). 16 Issues in Applied Linguistics and Translation. Shiraz: Shiraz University Press. 